\title{
Model of Translation Textbook for Teaching English as Foreign Language (TEFL) Pedagogical Purpose
}

\author{
Masitowarni Siregar ${ }^{1}$ \\ ${ }^{1}$ Faculty of Languages and Arts, Universitas Negeri Medan, Indonesia

\begin{tabular}{ll}
\hline \hline ARTICLE INFO ABSTRACT \\
\hline \hline Thicle history:
\end{tabular} \\ Article history: \\ Received April 02, 2019 \\ Revised May 03, 2019 \\ Accepted JUne 15, 2019

\begin{tabular}{l}
\hline Keywords: \\
Translation, \\
Textbook, \\
TEFL Pedagogical Purpose, \\
Model \\
\hline Clonflict of Interest: \\
None
\end{tabular} \\ Funding: \\ None \\ This study was aimed at developing the model of translation textbook \\ for teaching English as a foreign language purpose. Therefore, \\ Research and Development (R\&D) design was applied to develop the \\ translation textbook for TEFL pedagogical purpose. Moreover, there \\ are four steps to develop the textbook which drafting, peer review - \\ revise, expert review - revise and final texbook. The result of study \\ shows the while drafting the content of the textbook were 1) preface, \\ 2) Competences, 3) Presentation and 4) Assessment. Then from the \\ peer review, the contents of the textbook were developed to 1) \\ overview, 2) competencies, 3) orientation, and 4) assessment. From \\ the expert review, the content of textbook were deveoped to 1) \\ overview, 2) competencies, 3) orientation, 4) assessment, and 5) \\ further reading. In conclusion, this model has been developed \\ according to peer and expert views. Therefore, this model of \\ translation textbook is suggested to be used in English Education \\ Program in Indonesia. \\ Corresponding Author: Dr. Masitowarni Siregar, M.Ed., English and Literature Department, Faculty of \\ Languages and Arts, Universitas Negeri Medan, Jl. Willem Iskandar Pasar V - Kotak Pos No. 1589 - \\ Medan 20221, Indonesia. Tel. +62813-6141-5198. Email: siregarmasitowarni@yahoo.com

\begin{abstract}
1. Introduction
Translation (Translation) is one of the areas of competence reserved for students of English language education in a wide range of universities in the world. These skills help students to be able to transfer a message from a foreign language (the source language) into local language (target) or vice versa. Therefore, the Department of English language education throughout the university in Indonesia provides Translation
\end{abstract} \\ subject from English to Indonesian and vice versa. \\ However, translation is not an easy task; this is not as simple as activities that seeking the meaning of the \\ source language in the target language by using a dictionary. There are many requirements that must be taken \\ into consideration to produce good translations; such as the type of text, the cultural context and the word has \\ many meanings that must be adapted to the context. Therefore, many experts of translators have been \\ stringing some theories of how to produce a good translation which consistent with the intent of the source \\ language. Experts of translators indicated that the theories and concepts of translation must be provided on \\ the activities of training and learning translation so that the competence of the translation can be understood \\ by a student in accordance with the theory and the concept (PACTE 2005; Nababan, 2003; Gile, 1995) then \\ Ardi (2010) adds that by gaining the competence of a good translation, a translator is able to choose the best \\ way to solve problems in translation. \\ Therefore, to become a professional translator who require special education professional translation as in \\ professional translation aims to equalize the meaning of a text in the source language and the target language \\ and vice versa (Liu, 2000). Because of that, to be a professional translator, there are three stages that must be \\ passed by the prospective translators. They are: 1) bilingual practitioners, 2) the ability of realization of two \\ cultures (source and target) practitioners, and 3) sensitivity practitioners (changing and creative ability to
}


produce good prose) (Chau, 2000). Purpose and this stage is not the competence to be achieved by a prospective teacher or an English teacher competence complicated but this is to be achieved competence someone who wants to become a professional translator for the purpose of professional skills and part of career development.

Students of English education in North Sumatra who is an aspiring English teachers still required to be able to translate from English to Indonesian and vice versa, but for the purpose of teaching English subjects in class (Pedagogical Purpose). Therefore, strongly agree with Liu (2000). He said that the pedagogical translation is for the purpose of foreign language learning so that prospective teachers of foreign language (English) should understand the linguistic competence and stopped at the level of linguistic competence. Means, a prospective teacher or an English teacher competence requires a translation as an important means of learning a foreign language as a method of learning that can be used to deepen the understanding of the source text or to show one's understanding of the message in the original text. Therefore, this study is to elaborate the model of textbook that English Education Stusy Program needs to use in Indonesia.

\section{Literature Review}

\subsection{Translation}

As it is stated in Oxford Advanced Learner's Dictionary (2000) Translation is the process of changing something that is written or spoken into another language. Wiratno (2003) says that translation is a process of transferring message from SL into TL. SL or Source Language is an origin language, which is translated, while TL or Target Language is a final language that is used to express the result of translation. He states the previous statement in his book. But the definition of translation is not that simple. There are so many definitions about translation from many experts. They define translation in many ways.

According to Catford (1965:20), "Translation is the replacement of textual material in one language (SL) by equivalent textual material in another language (TL)" and Nida (1969) states that translation consists of reproducing in the receptor language the natural equivalent of the source language message, first in terms of meaning and second in terms of style. The definition of translation from the expert is not limited only on Catford's and Nida's point of view. There are several definitions stated by some experts.

However, translation deals with the meaning. Translation with correct structure is useless without the meaning. Larson (1984:3) states that translation means transferring the meaning of the source language into receptor language. And Newmark states a further view towards the transferring meaning in a translation. As he says (1988:5), Translation is rendering the meaning of a text into another language in the way that the author intended the text. Moreover, translation also deals with culture aspects. Kridalaksana, an expert in translation theory states on his book (1983). In brief, his view about translation is a transferring message among cultures and languages.

\subsection{The Function of Translation}

Basically, the special purpose or function of translation is as a medium of communications. As Duff (1989:5) says, "As a process of communication, translation functions as the medium 'across the linguistic and cultural barriers' in conveying the message written in the foreign languages." In other words, the function of translation is a medium or a means to carry the message from the SL to TL. And it is very helpful for people, which come from around the world in communication to each other.

As Nida \& Reyburn (1981:2) state, “Translation means communication because it has three essential elements to form a process of communication. The three essential elements are source, message, and receptor, and these elements must be found in all communication activities". In brief that, translation is a means in communication, that has source, message, and receptor which must be found in all communication activities.

\subsection{General Process of Translation}

Munday (2001) divide the process of translating into three stages system: 1) analysis of message in the SL; 2) transfer, and; 3) reconstruction of the transferred message in the TL. This process is described in the following figure. 


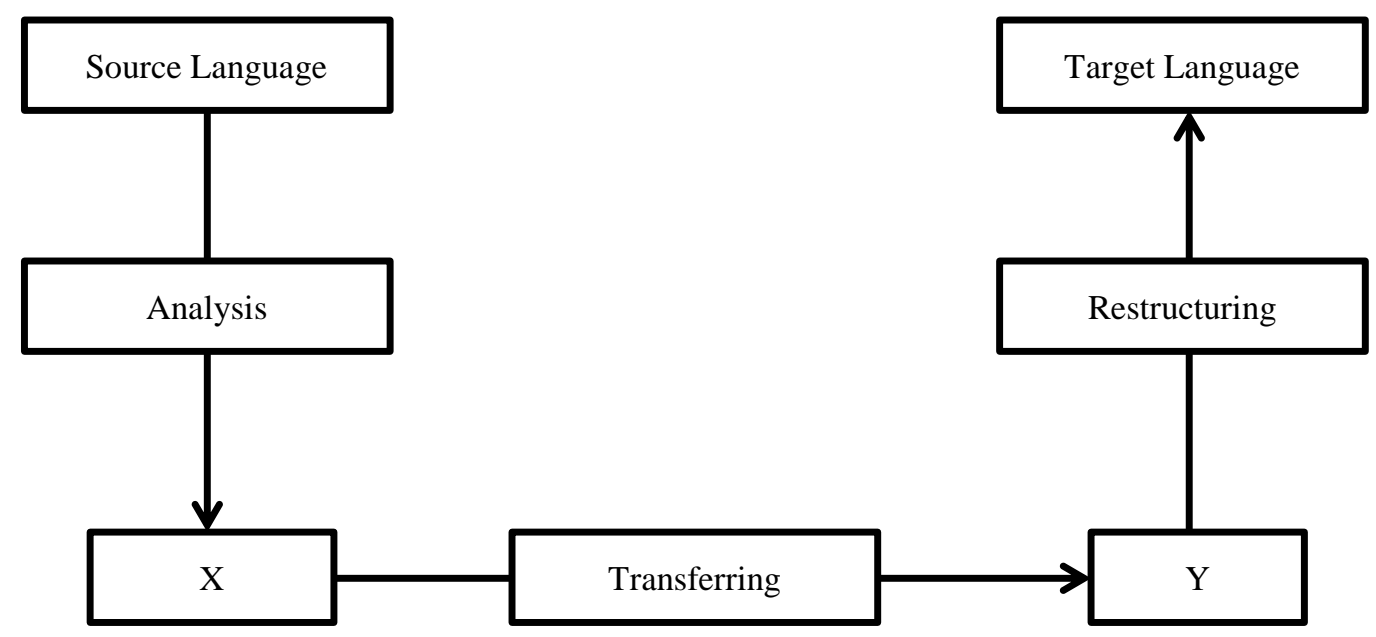

Figure 1. General Process of Translation

From the diagram, we can see that the source language is analyzing the grammatical relationship and the meaning of words and its combination. Then it transferred the meaning from SL into TL. The Reconstruction phase is the phase where the translator rewrites or re-expresses the materials in such a way that the translation product is readable and acceptable in terms of rules and styles in the TL. Furthermore, Nababan (2003) stated that the process of translation have three steps, those are 1) the analysis of the source language (SL), 2) transferring the message, 3 ) restructuring.

\subsection{Translation for Teaching English Purpose (TTEP)}

Actually, so many scholars that have been doing researches in translation studies such as Harries, Stanfield, PACTE, Pym and so on. Then, there are so many theories, models and concepts that they suggested in teaching a Translation subject. Therefore, many agree with Marta (2008) who said that none of the models presented by the scholars is inherently better than the others. It always depends on the aims of the researchers or lecturer, which model suits his/her purpose best. The PACTE model, for example, is excellent for the purpose of giving training to the prospective professional translators rather that to the purpose of giving lecturing to the prospective English teachers.

Because of that, Translation subject should be suitable to the teaching English purpose. So, it can be stated that the most suitable model of translation study for EESP students is TTEP, which is going to be familiarized in this paper. TTEP is a model of teaching translation for Teaching English as Foreign Language (TEFL) purpose that takes and states that translation is a language teaching technique because as many scholars ague (Malmkjaer, 1998), translation does not always fulfill real communicative function. In foreign language teaching, it is often used as a technique to ensure comprehension, to make the structure of target language transparent, to practice certain structures or to test the certain linguistic element. This type of translation is often referred to pedagogical translation (Heltai, 1996; Malmkjaer, 1998).

In so doing, if the purpose of the model is different, the competence that should be applied will be different. For instance, if the purpose is for professional translation or career, the competence that should be applied will be for professional translation. But if the purpose is for teaching English as foreign language, the competence that should be applied will be competence that related to teaching English purpose. Therefore, strongly agree with Liu (2000). He said that the pedagogical translation is for the purpose of foreign language learning so that prospective teachers of foreign language (English) should understand the linguistic competence and stop at the level of linguistic competence. It means that a prospective English teacher should apply translation as an important technique on teaching and learning a foreign language that can be used to understand the source text or to show one's understanding of the message in the original text.

Therefore, translation competence for prospective English teacher should be on basic competence and linguistics competence. It means that the students of EESP only need to know about linguistics competence in translation like semantic and pragmatic meanings in the certain text provided. But, to realize this competence to the students of EESP needs a study to arrange the material, topic, assessment and evaluation on related the basic and linguistic competence for prospective English teachers or the students of EESP.

\subsection{Translation for TEFL Purpose in Indonesia}


Currently, the Translation subject in English Education Study Program in university in Indonesia has not been focused on teaching English purpose. Some universities are still following PACTE but some did not follow any standards of translation since they just put whatever they want to put in Translation subject.

Teaching materials Translation is not the same at every university in North Sumatra. This happens because there is no cooperation between the university syllabuses. Each university has their own opinion, and almost all the lecturers that administer courses Translation refers to the translation model of the competencies set by PACTE. Then, PACTE in principle is not translation competence models for prospective teachers but rather to potential professional translators. In other words, the model used to develop the competence PACTE professional career in translation while the student is expected to use the translation knowledge in English Education focusing on the goal of teaching English (PACTE, 2000). It is clearly stated ole team PACTE (2005), which explains that the competency model of translation is the principle of science that directs the flow of translation to align source language to the target language (process, methods and procedures) and the profession (type of translation, user, and so on). Coupled with the absence of the same syllabus at the university, resulting in each faculty to determine and provide learning materials freely and lead to the teaching of translation on S1 students of English Education has not followed the standards of competence to be achieved as a candidate for an English teacher because it is not available.

Furthermore, teaching methods Translation is the duty and the right of each teacher to determine what method should be applicable for the learning process in line with expectations and achieve the goal of learning itself (Celce-Murcia, 2001; Brown, 2007). However, to achieve the learning objectives there should be a standard to be followed by the teacher. In teaching Translation, Fawcett (1997) proposed that the teaching of the theory of translation must consider three of the following: a) effective, b) cognitive, and c) psychomotor. In general, three things can be a reference to the lecturer that teaches Translation as an objective to make students as professional translators and students as future teachers of English. However, practically Fawcet develop these three sub-sections into a very complicated and refers to the aim to make the student as a professional translator plus not all teachers / lecturers are able to apply teaching methods or procedures of this translation (Ardi, 2015). However, most of the teachers still impose this method to the students of English Education S1. This happens because of the absence of any other reference to be followed by the teachers. In fact, Heltai (1996) and Malmkjaer (1998) has determined that in the teaching of English as a foreign language, Translation is used as a technique to convince the understanding, making the structure of language becomes transparent, to practice particular structure, or test certain linguistic elements. This translation type is referred to Translation as a base on Teaching English as a Foreign Language - TEFL Pedagogical Purpose.

In accordance with this statement, it should be a method that should be practiced in teaching the course Translation at S1 students of English Education is a method of directing students to use translation as a reference / techniques to teach English as a foreign language for students of S1 English Education is an aspiring language teachers UK.

In addition, the very important thing in teaching Translation is the assessment and the evaluation of the competency achievement. However, determining the appropriate assessment and evaluation which is in fact not a very easy thing for synchronizing the competencies expected to be in accordance with the type of evaluation are given in order to measure the achievement of competence can be achieved precisely. Therefore most of the trainer or lecturer of the course Translation often only assess student competence in a manner based on linguistic abilities, and they are focused only on the text of the competence of the translator (student) (House, 1997). To be honest, Marta (2008) says that the naturalness of the results of the translation itself still presents a problem to evaluators potential.

Therefore, the evaluation of the corresponding learning-based Translation TEFL pedagogical purpose in accordance with the competency given to students studying translation based TEFL pedagogical purpose. Not just predict whether the meaning of the source language is in conformity with the meaning of the target language. Strongly agree with the researchers McAlester (2000), which says that the modern techniques of educational evaluation can be applied to the evaluation of translation. To that end, as a course given to prospective English teachers, Translation must have a competency evaluation in accordance with the standards of competence that translation as a technique in teaching English as a second language.

\section{Method}

The method used in this study is Reseach and Development (R\&D). Started from drafting, peer-review, revise 1, expert review, revise 2 and final model of textbook. The peer review process, the researcher asked three (3) Translation lecturers to give comment qualitatively about the draft of translation textbook. After that, the textbook was developed based on the comments. After that, three (3) experts were asked to review the textbook quantitatively and qualitatively. Then, the final model of the textbook was developed based on expert review results and comments. 


\section{Results and Discussion}

\subsection{First Draft}

Based on the literature review and emperical study, first draft of translation textbook consisted of four (4) components. They are 1) preface, 2) Competences, 3) Presentation and 4) Assessment.

1) Preface

Preface is the first section in textbook. It is the general description about the materials presented in every chapter/unit. General description also gives first information or brainstorming efore the students study the textbook.

2) Competencies

Competencies is part of teaching material that contains the competencies / skills acquired by students after learning ends for each subject and topic.

3) Presentation

Presentation is a comprehensive description and presentation of teaching material. The presentation presents a detailed explanation of each part in the teaching material presented.

4) Assessment

Assessment is part of teaching material that aims to find out the extent to which students are able to understand and master the material in teaching material that has been learned. Assessment also serves to find out the weaknesses and strengths that occur during the teaching and learning process.

Physically Figure 2 below is an initial draft that contains the main components and subcomponents of TEFLbased Pedagogical Purpose Translation teaching materials 


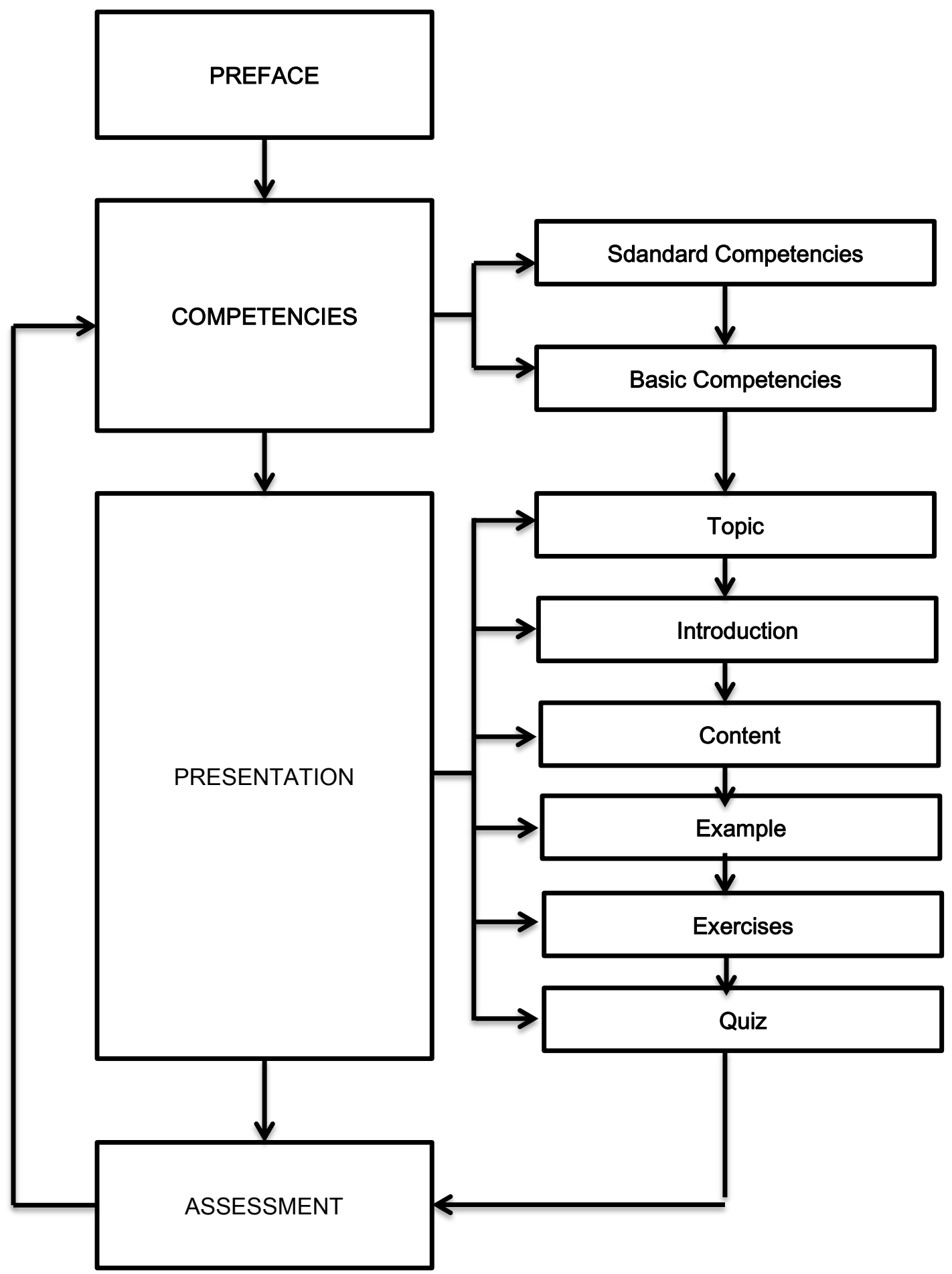

Figure 2: First Draft of Translation Textbook Based on TEFL Pedagogical Purpose

\subsection{Second Draft}

After the Draft Translation of teaching materials is finished, an initial assessment of the Draft teaching materials is carried out. The evaluation of teaching materials is carried out by peers (peer review). The number of peers involved in peer review was 3 people. The assessment is carried out to obtain comments, input and suggestions as well as constructive criticism from peers in an effort to improve the feasibility of teaching materials from the lecturer perspective. Peer assessment is important in the early stages of developing teaching material. The results of assessments from peers (peer review) are in the form of input, suggestions, or comments, and criticism. 
From the results of the Peer Review there are eight (8) things that were commented on and given advice by peers and this is indeed appropriate to improve the quality of teaching materials to be designed.

First, the word Preface according to peers should be changed to over view because the word over view is considered more appropriate for teaching materials.

Second, the competency or difficulty level both in terms of language and training in teaching materials must be adjusted to the level or level of students' English proficiency so that students are able to absorb learning properly and correctly.

Third, the presentation of teaching materials must be adapted to the following things: 1) The theory should not be too much, because the focus of this learning is so that students are able to translate practically and accordingly to them as prospective teachers, 2) the material seems too dense, therefore the material needs to be reduced and adjusted according to the level of student needs and loaded in accordance with the level of undergraduate students, 3) It should be adjusted to the number of meetings per semester so that the material is not too dense and lecturers supporting courses also have no difficulty in delivering all the material and time for activities, discussions, exercises and assignments, 4) Add examples of incorrect translations and correct translations to each discussion of the exercise results because by seeing the wrong and right students practically will easily understand and it is likely for them to be more interesting to learn mistakes and correct them with true and full of mo motivation and 5) The word presentation should be replaced with Orientation because the word Orientation is considered more appropriate for teaching materials.

Fourth, assessment must be more objectified according to the criteria of good and appropriate translation results because by using a good assessment students will be motivated and the level of accuracy of student translation will be measured accurately and accordingly for them as prospective English teachers.

Fifth, linguistics, in this case there is a very good suggestion given by colleagues that is generally the language used is relatively complex, especially in the theory and strategy, therefore, you should use simple language that can be understood by students. This is indeed very appropriate because the language used in teaching materials should be easily understood by users both students and lecturers so that learning achieves its goal of educating the life of the nation rather than making it difficult for students and lecturers.

Sixth, the learning process must be emphasized more on the activities of students as a group, together and individually. This is necessary because by using this technique students not only learn by themselves but also can share with other fellow students so that it will be more interesting and students more motivated. Then, the number of group activities must be reduced so that students can be independent. This is also necessary because the results we want at the end of learning are that each individual is able to translate well and in accordance with their needs as prospective teachers.

Seventh, layout is also a concern of peers and there are three (3) suggestions from peers namely 1) the overall arrangement needs to be reorganized and improved because according to colleagues the arrangement of teaching materials is made less attractive and looks less professional, 2) adjust the example to strategy and translation steps so that students can easily understand the theory and instructions in teaching material, and 3) the font in the example should not be the same as the font in the explanation of the theory and steps. This is so students do not get bored and easily see and understand the exercises with full concentration and motivation in doing the exercises in the teaching material.

Eighth, another thing that is given input by colleagues is that instructions in each topic must be clear to lecturers and students so as not to confuse, instructions in teaching materials must avoid ambiguous words so that both lecturers and students are able to properly understand the instructions in the teaching material. Then, instructions for the use of teaching materials must be well described for lecturers and students so that it is clear which parts are part of students and which parts are part of lecturers and lecturers will be easier to convey or explain topics to students.

Based on these constructive suggestions, input and comments, the teaching material that has been created will be revised according to peer input and matters that are deemed unnecessary will also be accepted but will not be realized. To develop this teaching material, the revision stage is carried out in accordance with the next sub-section.

To obtain adequate quality of teaching materials those are relevant to the needs of students and the workplace. The next step is to do a revision of stage 1. Sources of references, references, and data for improvement in the revision of stage 1 are the result of peer review comments, suggestions and or criticism from peers.

In addition, the improvement of teaching materials is also based on knowledge and experience as well as other literature and empirical data that is carried out continuously to get teaching materials that are 
appropriate and relevant to the needs of students and workplaces namely work as English teachers. Then, the physical structure, layout and design of teaching material results after revision with input from the results of peer review have substantial changes, especially the main components. The main components of teaching materials consist of 1) overview, 2) competencies, 3) orientation, and 4) assessment.

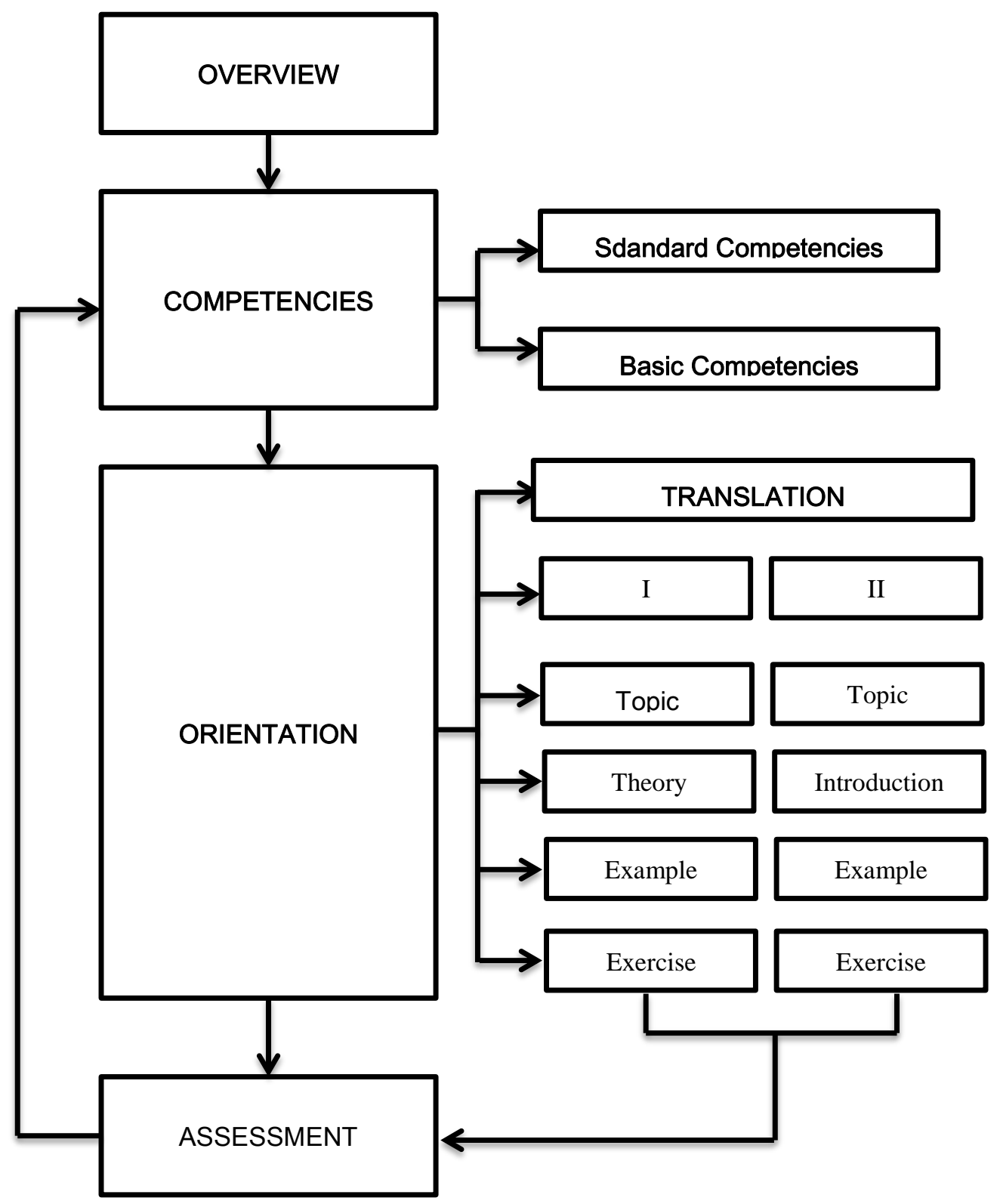

Figure 3: Second Draft of Translation Textbook Based on TEFL Pedagogical Purpose

\subsection{Final Draft}

The next step is the feasibility test of teaching materials by experts or expert judgment or expert justification. Before the Translation testbook is implimented, the teaching material needs to be assessed for eligibility from an expert or expert point of view. Expert testing is carried out in triangulation involving 3 (three) relevant experts and in accordance with their needs and fields. The three experts are 1) experts in linguistics (English), 2) experts in education (English) and 3) experts in Translation. The three expert teams have different expertise and abilities, so as to obtain data and information as accurate and valid as possible, the expert team assesses the Translation teaching material based on their respective expertise and competence.

Basically, the feasibility test for teaching materials conducted by a team of experts produces two types of testing data, namely quantitative data and qualitative data. The data of the feasibility of teaching materials is quantitative using a questionnaire that contains assessment components using the Linkert Scale. Then the Linkert Scale is converted to a score. Then the score of each expert is added up and the final or average value 
is searched. Then the average value is converted and interpreted into five categories with different levels of eligibility criteria.

Table 1: Evaluation score from 3 experts for Translation Textbook.

\begin{tabular}{|c|c|c|c|c|c|}
\hline \multirow{2}{*}{ No. } & \multirow{2}{*}{ Aspects } & \multicolumn{2}{|c|}{ Score from 3 Experts } & \multirow{2}{*}{ Total } & \multirow{2}{*}{ Mean } \\
\hline & & T1 & $\mathbf{T 2}$ & & \\
\hline 1 & Linguistics & 4.55 & 4.51 & 9.06 & 4.53 \\
\hline 2 & Method & 4.33 & 4.08 & 8.41 & 4.20 \\
\hline 3 & Product and Content & 4.26 & 4.26 & 8.52 & 4.26 \\
\hline 4 & Layout & 4.61 & 4.24 & 8.85 & 4.43 \\
\hline \multicolumn{2}{|l|}{ Total } & $\mathbf{1 7 . 7 5}$ & 17.09 & 34.84 & 17.42 \\
\hline \multicolumn{5}{|c|}{ Total Mean } & 4.36 \\
\hline
\end{tabular}

Referring to Table 1 of the results of the assessment by the expert team, cumulatively, the average results of the expert team's feasibility test showed that teaching materials scored 4.36 points. Therefore, based on quantitative data it can be concluded that TEFL-based Pedagogical Purpose Translation teaching materials are good, relevant and appropriate for use by English Education students who are prospective English teachers.

In the context of qualitative assessments, the expert team also provided comments, suggestions, and recommendations on the teaching materials it valued. Comments, suggestions and recommendations are references, data sources and references for the improvement and revision of the teaching material. In more detail, the following table 4.15 is the result of corrections, suggestions, and comments on TEFL-based Pedagogical Purpose Translation teaching materials.

Based on input from the expert team, in general the physical structure and sections, as well as sub-sections and sub-sections consist of three main sections as presented in the following sections.

First, the cover page consists of the front cover and back cover. The front cover page consists of the title and sub-headings (if any) teaching material, the name of the author without an education degree, the author's affiliation to work and the logo and the name of the publisher (if any) while the back cover consists of information about the contents of the book and the information of the author of the book and also the information of the publisher and ISBN (if any). The cover page also contains illustrations or images that correspond to the essence of TEFL-based Pedagogical Purpose Trasnlation teaching material.

Second, the introduction, the introductory section contains 1) About the Course Book, 2) Acknowledgment, 3) Scope and Squence, 4) Table of Contents, and 5) Abverbiation List (if any).

Third, the contents of teaching materials, the main part of the contents of teaching materials consists of 5 (five) main parts in each chapter, namely 1) Preview, 2) Competencies, 3) Orientation, 4) Assessment 5) Further Reading.

1) Preview

Preview is the initial part of teaching material in each chapter. The preview presents a general description of the material presented in each chapter / unit of study. The general description also provides preliminary knowledge or a type of brainstorming before students study further.

2) Competencies

Competencies is part of teaching material that contains the competencies / skills acquired by students after learning ends for each subject and topic.

3) Orientation

Orientation is a comprehensive description and presentation of teaching material. The presentation presents a detailed explanation of each part in the teaching material presented.

\section{4) Assessment}

Assessment is part of teaching material that aims to find out the extent to which students are able to understand and master the material in teaching material that has been learned. Assessment also serves to find out the weaknesses and strengths that occur during the teaching and learning process.

5) Further Reading

SALTeL Vol. 2, No. 2, July 2019: $72-82$ 
Further Reading contains references that relate to the topic of Translation being studied. Further Reading serves to enrich knowledge and understanding and improve students' translating skills independently.

Physically, the structure and design of teaching materials in the content section which consists of 5 (five) main components, namely 1) Preview, 2) Competencies, and 3) Orientation, 4) Assessment, and 5) Further Reading are presented in Figure 4 below.

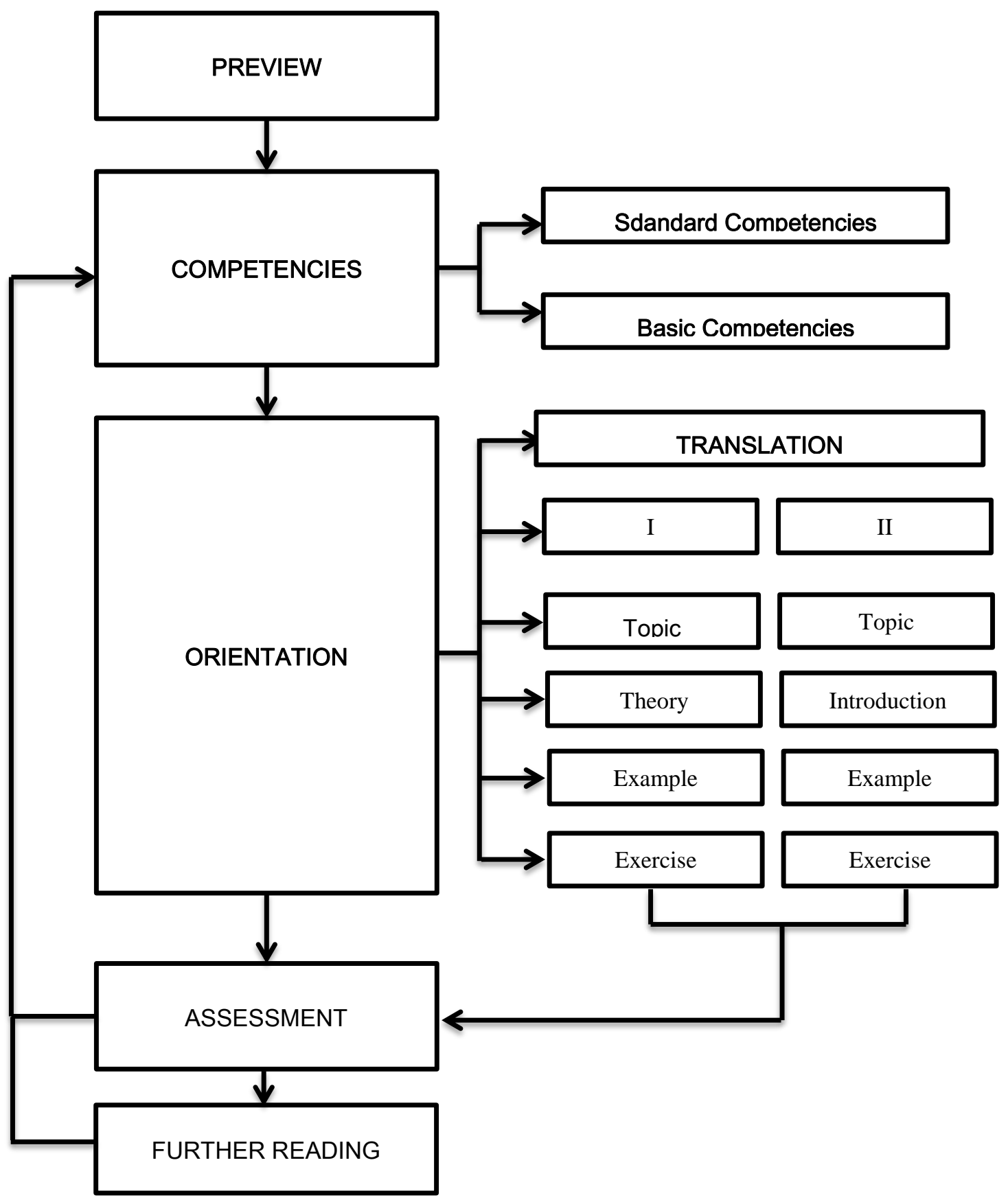

Figure 4: Final Draft of Translation Textbook Based on TEFL Pedagogical Purpose

\section{Conclusion}

Translation Textbook Based on TEFL Pedagogical Purpose is very suitable for Students of English Education Pregram in Indonesia as they are going to be an English teacher not a professional translator. The first draft of the textbook consisted only preface, competencies, presentation and assessment. In the second draft consisted overview, competencies, orientation and assessment. Then, after the experts gave the comments, the textbook was developed to five (5) main contents. They are preview, competencies, orientation, assessment, and further reading. This final draft has been developed according to peer and expert view. 


\section{References}

Ardi, H. (2010) Analisis Teknik Penerjemahan dan Kualitas Terjemahan Buku "Asal-Usul Elite Minangkabau Modern: Respons Terhadap Kolonial Belanda Abad ke XIX/XX”. Masters Thesis, Universitas Sebelas Maret.

Ardi, H. (2015). Pengantar Penerjemahan (Introduction to Translation). Jakarta: Sukabina Press.

Brown, H. D. (2007). Teaching by Principle; An Interactive Approach to Language Pedagogy. Third Edition. New York: Pearson Longman.

Catford ,J.C.,( 1965). A Linguistic Theory of Translation. Oxford :

Celce-Murcia, M. (2001). Teaching English as a Second or Foreign Language. Third Edition. Heinle: Language Learning.

Chau, S.S.C. (2000). Hermeneutics and the Translator: The ontological Dimension of Translating. Multilingua, 3 (2), 7 - 71.

Duff, A. (1989). Translation. London: Oxford University Press.

Fawcett, P. (1997) Translation and Language. Linguistic Theories Explained. St. Jerome, Manchester.

Gile, D. (1995). Basic Concepts and Models for Interpreter and Translator Training.

Amsterdam/Philadelphia: John Benjamins.

Heltai, P. (1996) Fordíthatjuk-e Richard Couer-de-Lion-t Hódító Vilmosnak? In: Iskolakultúra, 16(18) 6285.

House, J. (1997) Translation Quality Assessment. A model revisited. (2nd edition) Gunter Narr Verlag, Tübingen.

Larson, M. L. (1984). Meaning-Based Translation: A Guide to Cross-Language Equivalence. Lanham Md: University Press of America.

Liu, X. (2000). Article translated from New York Times, Marriage: 1\% Inspiration, 99\% Perspiration, Guangming Daily, 25th April.

Nida, E. A. (1969). Science of translation. Language 45.483-498. D. Terence Langendoen

Nida, E.A. and Taber, C. R. (1969). The Theory and Practice of Translation. Leiden: EJ.Brill.

Malmkjaer, K. (ed) (1998) Translation and Language Teaching. Language Teaching and Translation. St. Jerome, Manchester.

Marta, L. (2008). Studies in the Development of Translation Competence. Ph.D. Dissertation. Alkalmazott Nyelveszeti Program.

Munday, J. (2001). Introducing Translation Studies: Theories and Applications. London and New York: Routledge.

McAlester, G. (2000) The Evaluation of Translation into a Foreign Language. In: Schäffner, Ch. \&Adab, B. (eds) Developing Translation Competence. John Benjamins, Amsterdam/Philadelphia, pp. 229241.

Nida, E. A. and Reyburn, W. D. (1981) Meaning Across Cultures. Maryknoll, New York: Orbis.

PACTE. (2005), 'Investigating Translation Competence: Conceptual and Methodological Issues', Meta, 50, (2), 609-619.

PACTE (2000). "Acquiring Translation Competence: Hypotheses and Methodological Problems in a Research Project". In: Beeby, Allison, Ensinger, Doris. i Presas, Marisa (eds.). Investigating Translation. Amsterdam: John Benjamins. 99-106.

Nababan, M.R. 2003. "Arah Penelitian Penerjemahan", Makalah disajikan dalam Kongres Nasional Penerjemahan, di Tawangmangu, 15-16 September 2003. 